\title{
Intention for Voting in Pakistan: the Role of Social Media, Ethnicity, and Religiosity
}

\author{
Jamshed Butt; Mohammad Awang \\ Limkokwing University of Creative Technology \\ Email: jamshedbutt.phd@gmail.com
}

http://dx.doi.org/10.18415/ijmmu.v4i5.88

\begin{abstract}
The issue "Exploring Social Media, Ethnicity, and Religiosity Role on Intention for Voting in Pakistan" is a huge study embracing more issues. The politics of Pakistan is basically the politics of semantic groups. Pakistan is a multilingual state more than six languages. There are 245 religious parties in Pakistan, as elaborated by the Daily Times research. The use of social media sites in Pakistan peaked to its maximum after announcement of election schedule by the Election Commission of Pakistan in March 22, 2013. Most of the political parties used it for the recent elections in Pakistan to promote their agenda and attract country's 80 million registered electors. The theories interact with the research topic are theory of reasoned action (TRA), theory of planned behaviour (TBP), Social Cognitive Theory (SCT), and Social Ecological Model (SEM). The variables introduced in this research are Social Media, Ethnicity, Religiosity, and Intention for Voting. The proposed model have four dependent variables. A survey constructed from 24 questions were used to capture the respondents' opinions regarding eight variables in a 7-likert scale. A sample of 1336 Pakistani citizen were collected. Data was collected within three months' period, from 1 March 2015 until 31 May 2015. Distribution of the survey took place in four major cities; Karachi, Lahore, Faisalabad, and Rawalpindi/Islamabad. Data obtained from the survey is analysed by utilizing the software Statistical Package for the Social Sciences (SPSS). The proposed research model have three hypothesis that demonstrate the relations. From the three hypotheses, two hypothesis are significant while one hypothesis are rejected. Results highlight on the importance of social media in politics aspects, therefore further research is recommended.
\end{abstract}

Keywords: Social media; Ethnicity; Religiosity; Attitude towards politics; Pakistan

\section{Background}

This issue "Exploring Social Media and Other Crucial Success Elements of Attitude towards Politics and Intention for Voting in Pakistan" is a huge study embracing more issues. E-participation plays an important component to expand politics opportunities by allowing seniors for connecting with each other and using their elected staff. E-participation utilization in Pakistan is developed after the attacks of 11th-September-2011. This kind of study endeavours to understand behaviour and intention of Pakistani people about the effects of sociable press and also other critical elements in political attitude and voting intention (Khan \& Shahid 2010). 
In 1947 Pakistan had its dependence from United Kingdom, and the political system that governance the Pakistan state continuously changed between democratic military and rule dictatorships. Three attempts in a vastly operational democratic changeover of power in the past produced an assassination, a military jour and a great hassle of martial rules. However, the fifth greatest democracy found in the world, witnessed a historical event in the recently country's democratic process because the 2013 General Election provided the first ever democratic transfer of power. The latest votes too had been blemished by simply attack but that didn't break the people right from voting in good sized quantities and documenting amongst the best playoff turnout costs in Pakistan's election background.

With expanding educational opportunities, arising middle class, and growing access and usage of the modern social media by the nation's youth, Pakistan is now in the midst of a dramatic social and political transformation that is likely to change the face of politics in the coming decades. The arrival of this new era has the potential to eventually end the old feudal style politics of patronage, and replace it with a truly participatory democracy and vastly improved governance (Haq 2011). The use of social media sites in Pakistan peaked to its maximum after announcement of election schedule by the Election Commission of Pakistan in March 22, 2013. Most of the political parties used them for the recent elections in Pakistan to promote their agenda and attract country`s 80 million registered electors (Yusuf 2015).

The politics of Pakistan is basically the politics of semantic groups. Pakistan is a multilingual state, where the Pakhtuns, Sindhi, Balochi, Punjabi, Mahajir and Siraiki identities are expressed through Pashto, Sindhi, Balochi, Punjabi, Urdu and Siraiki languages. There are 245 religious parties in Pakistan, as elaborated by the Daily Times research. Of these, 28 openly take part in politics, 104 claim to focus on jihad and 82 on sectarian concerns. 20 parties are of 'Tablighi' proselytization. The remaining 23 are involved in activities of a mixed nature (Shehzad 2011; Awami Politics 2015).

Within the recent decade, the trend of political campaigns moves towards using Internet based techniques. Political counsellors and nominees emigrate from using traditional advertisement methods to the use of the Internet and e-mail (Ayanso et al. 2014). Dalbey (2013), suggests that within two years most of the campaigns cost and time will be web-based campaigns. In Pakistan, the 2013 General Election witnessed the also introduction of social mass media, which include Twitter, since an instrument of election marketing campaign and electoral mobilization (Masood 2013). Designed for the very first time on Pakistani politics social marketing played a dynamic role, because violent attacks on partly political rallies before obligated political people to place a larger focus on the internet promotioning in this selection (Ahmed \& Skoric 2014). This study was aiming to investigate the role of social media in the intention for voting. In addition, the impact of ethnicity and religiosity on intention for voting was investigated as well.

\section{Conceptual and Theoretical Framework Intention for Voting}

There are a number of models that inspect the joint role of normative effect and attitudes on behaviours including Ajzen and Fishbein's (1980) TRA and the theory of planned behaviour (TPB; Ajzen 1985). According to the TRA, variables such as demographics play a role in creating behavioural and normative beliefs an individual has about a behaviour intention. These behavioural and normative beliefs combine to shape the individual's attitudes and subjective norms, which are indirect predictors of behaviour intention. Voting is a planned action that involves a single, concrete behavioural act, and thus provides a good context for understanding the social and psychological predictors. Studies that have examined predictors of voting behavior, however, have been limited. Past research has applied the TRA both to investigate the success of getting out the vote efforts (Johnson 2007) and to assess directional 
voting compliance in candidate elections (Singh et al. 1995) and find results consistent with the model. Nevertheless, as noted previously, referendum voting is distinct from general election voting in that it involves significant cost to many voters (i.e., those who own property) and the outcomes of the act may not be immediate or tangible (Maloney et al. 2013; Ajzen \& Fishbein 1980; Cialdini et al. 1990).

\section{Theory of Planned Behaviour (TPB)}

In 1985, Icek Ajzen developed the theory of reasoned action TRA and proposed the theory of planned behavior (TBP). TBP is a social reasoning theory that has directed a large mainstream of theorybased exploration on human behaviour. Based on systematic review of prior research Ajzen decide to refine the TRA theory that proposed in 1975 by Martin Fishbein and Icek Ajzen by introducing additional predicting element perceived behavioural control PBC. The theory of planned behaviour specifies that some or all of the following four main psychological variables influence our behaviour: intention, attitude, subjective norm, and perceived behavioural control. The combination of an individual's expectations about performing a behaviour and the value attached to that behaviour form the conceptual basis of this theory. Intention to do a behaviour is the dominant element of whether or not an individual engages in that behaviour. Intention is reflected in a person's willingness and how much effort that individual is planning to exert to perform the behaviour. The stronger a one's intention to perform a behaviour, the more likely one will be to engage in that behaviour. Thus, if someone has strong intent to go for a walk this afternoon, that person is likely to go for that walk.

\section{Social Cognitive Theory (SCT)}

In 1977, Bandura proposed the Social cognitive theory (SCT). Bandura relies on an academic experiment governed by Miller and Dollard Miller (1941). But some scholars stated that the origin of the theory is the book of Edwin B. Holt and Harold Chapman Brown's 1931 book theorizing that all animal action is based on fulfilling the psychological needs of "feeling, emotion, and desire". The theory is known as social learning theory and clarifies human behaviour in terms of dynamic, mutual, and three dimensional models. The proposed three dimensions are personal factors, environmental influences, and behaviour. An elementary principle of SCT is that individuals learn not only over and done with their own practices, but also by seeing the activities of others and the results of those actions.

\section{Social Ecological Model (SEM)}

Bronfenbrenner is the founder of social ecological term, as he claimed the model in the 1970s and claimed the associated theory in 1980s. The social ecological model aids to realise aspects upsetting behaviour and also offers direction for evolving fruitful agendas over social environments. Social ecological models highlight many altitudes of effect (such as separable, relational, structural, public and public policy) and the impression that behaviours both figure and are formed by the social setting. The values of social ecological models are reliable with social cognitive theory notions which propose that producing an environment favourable to change is significant to creation it at ease to approve well behaviours. 


\section{Literature and Proposed Model Development}

The study is examining the impact of religious, ethnicity and social media on the citizens' intention for voting. Therefore, four first order dimensions are constructing the proposed model.

For most individuals, religious and beliefs are not static and developed over time. Studies of religion have noted that as people stage of development, their association with both recognised religious societies and their own particular beliefs change (Argue, Johnson, and White 1999; Ingersoll-Dayton, Krause, \& Morgan 2002; Wilson \& Sherkat 1994). Religiosity is a complex concept and difficult to define (Holdcroft 2006). It would seem that one had to believe that either religiosity was influenced by macro-factors like rationalization or differentiation or that individuals were rationally choosing religion (and would demand less religion in regulated markets) or that individuals were mainly influenced by the fact that they had or had not been exposed to religious socialization in their childhood (Holdcroft 2006). In Pakistan, There are 245 religious parties, as explained by the Daily Times research. Of these, 28 responsively affect in politics, seven have been participating in the electoral process. Three were represented in the congress namely JUI-F, JUI-Sami, and Sipah-e-Sahaba. A continuous question is, whether the religiosity played a role in the success of fail of that religion based parties (Smith 2009, Yilmaz 2005). Religions are well-thought-out to effect political attitudes. However, there at least two potential paths shape this affect. First, religions effect political attitudes as a result of the value system. Religious teachings individuals the significance of some values and degrade the position of other values, and thus, outline their individuals' value system (e.g. Schwartz \& Huismans 1995). This value system would then affect the political attitudes and beliefs of individuals that guides their political attitudes (Van Gyes \& De Witte, 1999). Alternatively, second, Religions influence political attitudes directly. For example, in Belgium, Most of the Roman Catholics in Flanders choose the Christian democrat party during the voting process (Duriez et al. 2000). Therefore, this study tested the following preposition.

\section{Religiosity Has a Positive Effect on Intention for Voting in Pakistan}

Ethnicity is an umbrella concept that "easily embraces groups differentiated by colour, language, and religion; it covers "tribes," "races," "nationalities," and castes" (Horowitz 1985). Most of the recent researches in the political issues use this concept of ethnicity classification (Chandra 2012; Varshney 2003). In USA, studies conclude that the main factor after political ideology was race. Race plays a major role in the election of Obama (Harvard IOP 2015). Logan et al. (2012) concluded that 3+ generation of blacks are more likely to participate and vote in political elections than whites. He also concluded that Asian and Latinos are much more dislike to participate and vote compared with whites. Therefore, the study tested the following preposition.

\section{Ethnicity Has a Positive Effect on Intention for Voting in Pakistan}

Social media refers to an environment of interactions among people in which they create, share, exchange and comment on contents among themselves in virtual communities and networks. It is defined as "a group of Internet-based applications that build on the ideological and technological foundations of Web 2.0 and that allow the creation and exchange of user-generated content. Furthermore, social media employ mobile and web-based technologies to create highly interactive platforms for individuals and communities to share, co-create, discuss, and modify user-generated content. It introduces substantial and pervasive changes to communication between organizations, communities, and individuals. The act of writing was the act of sharing (Wang et al. 2012). Social media widespread in most of the societies and the fast spread of news within these virtual societies encourage more and more voters to relay on the social media during the political process (Birkbak 2013). It is clear that whenever publics heavily using 
the Internet, they will explore political news and formulate political communities on the net and propitiations have no choice to use it (Enli et al. 2013). According to social media experts, Facebook undeniably played a very important role in the lawyers' movement against General Musharraf in March 2007. While Facebook was the meeting point for cyber activism, Twitter was useful in spreading the word out to the broader world. It significantly helped in gaining the attention of the world community (Minhas et al. 2015). Recent cases in Egypt, Tunisia, and Lebanon in 2011 are proof that social media can play a role in instigating political change (Faris 2010; Patel 2015; Xenos et al. 2014; Kemp et al. 2015). Therefore, the study tested the following preposition.

\section{Social Media Has a Positive Effect on Intention for Voting in Pakistan}

The aim of this research is to investigate the impact of social media, ethnicity, and religiosity on intention for voting in Pakistan. Figure 1, demonstrate the proposed theoretical frameworks, where intention for voting is the dependent variable while social media, ethnicity, and religiosity are the independent variables.

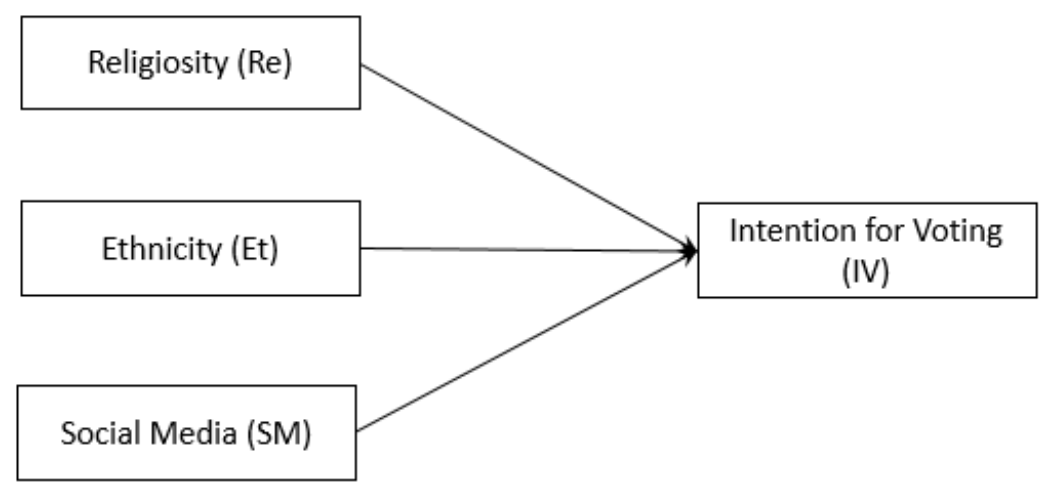

Fig. 1 Research proposed model

\section{Methodology}

The major results that answer the research questions were acquired in quantitative techniques. The study used a well-structured questionnaire that was distributed among a selected random stratified sample of adults in four cities in Pakistan. The data was analysed by using SPSS ver. 20. On the other hand, the proposed model formulation and the survey questions was constructed from a systematic literature review that normally known and qualitative approach.

Population is defined as a group of people who share common characteristics (Black 1999). The population provides the sample and the sample is further used to collect data required to make conclusions. According to an estimate, there is about 42.7 million internet user in Pakistan and half of them are mobile user (Liu 2015). The internet users in the major cities of Pakistan will be the target population for this thesis. In this study, the collected sample size was 1336 case from the major four 
cities. Based on population, this sample size have $95 \%$ confidence level and 3\% confidence interval. Sample collected from each city is presented in Table 1.

Table 1 Data collection distribution.

\begin{tabular}{cccc}
\hline City & Population (Million) & Internet uses & Sample \\
\hline Karachi & 13.13 & $15,165,000$ & 675 \\
Lahore & 7.13 & $8,241,000$ & 367 \\
Faisalabad & 2.85 & $3,339,000$ & 149 \\
Rawalpindi/Islamabad & 2.86 & $3,297,000$ & 147 \\
\hline Total & 25.96 & $42,718,893$ & 1336 \\
\hline
\end{tabular}

Data was collected within three months' period, from 1 March 2014 until 31 May 2015. The researcher with the facilitation of another four persons distributes the survey and collects it with direct collection methods. Distribution of the survey took place in four major cities; Karachi, Lahore, Faisalabad, and Rawalpindi/Islamabad; and inside every city the distributions happened randomly in the city centre, malls, and the major public Universities. The survey distributer introduced the aim and directions of the questionnaire to the participants before giving them enough time to fill in the survey and collect it. Participants informed clearly that joining the survey is voluntary.

A survey of 24 questions was formulated from literature. Table 4.2 summarize the survey map with its sources. 
Table 2 Survey questions

\begin{tabular}{|c|c|c|}
\hline Variable & Source & Items \\
\hline $\begin{array}{l}\text { Intention for } \\
\text { Voting }\end{array}$ & $\begin{array}{l}\text { Lampas et al. } \\
\text { (2013) }\end{array}$ & $\begin{array}{l}\text { - I am convinced that I will vote on the future elections. } \\
\text { - If I had to decide, I would vote in the next election. } \\
\text { - I would recommend others to vote on the future elections. } \\
\text { - } \quad \text { I have positive things to say about voting and elections. }\end{array}$ \\
\hline Ethnicity & $\begin{array}{l}\text { Phinney \& Ong } \\
\text { (2006) }\end{array}$ & $\begin{array}{l}\text { - I have spent time trying to find out more about my ethnic group } \\
\text { such as history, tradition, and customs. } \\
\text { - I have often done things that will help me understand my ethnic } \\
\text { ground better. } \\
\text { - I have often talked to other people in order to learn more about } \\
\text { my ethnic group. } \\
\text { - I have a very strong sense of belonging to my own ethnic group. } \\
\text { - I understand pretty well, what my ethnic group membership } \\
\text { means to me. }\end{array}$ \\
\hline Religiosity & $\begin{array}{l}\text { Worthington, et., } \\
\text { al (2003) }\end{array}$ & $\begin{array}{l}\text { - } \quad \text { I often read books and magazines about my faith. } \\
\text { - } \quad \text { I make financial contributions to my religion. } \\
\text { - } \quad \text { I spend time trying to grow and understanding of my faith. } \\
\text { - } \quad \text { Religiosity is especially important to me because it answers many } \\
\text { questions about the meaning of life. } \\
\text { - } \quad \text { My religious beliefs lie behind my whole approach to life. } \\
\text { - } \quad \text { I enjoy spending time with others of my religious affiliation. } \\
\text { - } \quad \text { Religious beliefs influence all my dealing in life. } \\
\text { - It is important to me to spend periods in private religious thought } \\
\text { and reflection. } \\
\text { - I enjoy working in the activities of my religious organization. } \\
\text { - I keep well informed about my religious group and have some } \\
\text { influence in its decision-making. }\end{array}$ \\
\hline Social Media & Espostito (2012) & $\begin{array}{l}\text { - To learn more about the candidate/campaign. } \\
\text { - } \quad \text { To learn more about issues that is important to me. } \\
\text { - } \quad \text { To keep up to date with this candidate's campaign and events. } \\
\text { - } \quad \text { To help me decide who to vote for in the election. }\end{array}$ \\
\hline
\end{tabular}

\section{Findings}

Demographic Analysis

Demographic information reported that $54 \%$ are females, $55.3 \%$ are aged between 19 to 30 years, and $35.7 \%$ have a bachelor level of education, a majority of 38.9 have income less than $21 \mathrm{~K}$ Rs., 46.9 are married, and 42.1 are Punjabi. Table 3, shows a full set of the demographic analysis of the 1336 respondents. 
Table 3 Respondents' profile

\begin{tabular}{|c|c|c|c|}
\hline \multicolumn{2}{|l|}{ Characteristic } & Frequency & Percent \\
\hline & Male & 614 & 46.0 \\
\hline & Female & 720 & 54.0 \\
\hline & $18-22$ year & 404 & 30.3 \\
\hline & 23-30 year & 467 & 35.0 \\
\hline & $31-40$ year & 304 & 22.8 \\
\hline & 41-50 year & 81 & 6.1 \\
\hline & More than 50 year & 78 & 5.8 \\
\hline & Less than $21 \mathrm{k} \mathrm{Rs}$. & 519 & 38.9 \\
\hline & $22-25$ k Rs. & 279 & 20.9 \\
\hline & 26-50 k Rs. & 379 & 28.4 \\
\hline & 51-75 k Rs. & 91 & 6.8 \\
\hline & More than $75 \mathrm{k}$ Rs. & 66 & 4.9 \\
\hline & Single & 575 & 43.1 \\
\hline & Married & 626 & 46.9 \\
\hline & Divorce & 70 & 5.2 \\
\hline & Widowed & 63 & 4.7 \\
\hline & Primary & 160 & 12.0 \\
\hline & Matriculation & 196 & 14.7 \\
\hline & Intermediate & 234 & 17.5 \\
\hline & Bachelors & 476 & 35.7 \\
\hline & Postgraduate & 268 & 20.1 \\
\hline & Punjab & 561 & 42.1 \\
\hline & Pathan & 194 & 14.5 \\
\hline & Sindhi & 193 & 14.5 \\
\hline & Saraiki & 120 & 9.0 \\
\hline & Muhajir & 160 & 12.0 \\
\hline & Balochi & 74 & 5.5 \\
\hline & Others & 32 & 2.4 \\
\hline
\end{tabular}

\section{Descriptive Statistics of Research Variables}

The study has four variables, and every variable have multiple items, which are representing the respondents' evaluation in a scale of seven degrees (Likert 7-scale). The mean value of the items of every variable is calculated by using SPSS software. Table 4 shows the numerical representation of every variable along with its standard deviation value. For the variable Intention for Voting, respondents' evaluation is positive with a mean value of $(4.33+1.322)$ that represents a percentage of $61.9 \%$. Then, for the variable Social Media, respondents' evaluation is positive with a mean value of $(4.76+2.10)$ that represents a percentage of $68 \%$. Then, for the variable Religiosity, respondents' evaluation is positive with a mean value of $(5.01+1.76)$ that represents a percentage of $71.60 \%$. Then, for the variable 
Ethnicity, respondents' evaluation is positive with a mean value of $(4.35+1.727)$ that represents a percentage of $62.1 \%$.

Table 4 Descriptive analysis

\begin{tabular}{llc}
\hline & Mean & Std. Dev. \\
\hline Religiosity & 5.0121 & 1.75949 \\
Ethics & 4.3462 & 1.72787 \\
Social Media & 4.7597 & 2.10667 \\
Intention for Voting & 4.3301 & 1.32291 \\
\hline
\end{tabular}

\section{Reliability Analysis}

Reliability statistics show that all constructs' scales have an adequate Cronbach's alpha values more than 0.7 . Table 5 , shows the reliability statistics of the research variables.

Table 5 Reliability of the constructs

\begin{tabular}{lcc}
\hline Constructs & Cronbach's Alpha & No of items \\
\hline Religiosity & 0.910476 & 10 \\
\hline Ethics & 0.884803 & 6 \\
\hline Social Media & 0.935405 & 4 \\
\hline Intention for Voting & 0.77743 & 4 \\
\hline
\end{tabular}

\section{Path Coefficient}

Path coefficient is important to assess the confirmation of a relation between variables. $\mathrm{P}$ value and $\mathrm{T}$ statistics are used to significant existence of a relation while Beta value is used to assess the significant level of a relation (Hair, 2015). The rule of thumb for $\mathrm{P}$ value is less that 0.05 and for $\mathrm{T}$ statistics is more than 1.96 (Hair, 2015). Table 6 shows the associated path coefficient values for the three desired relations of the model and Figure 2 shows the path coefficient estimation values. Two relations are significant with $\mathrm{P}$ value less than 0.05 , but the relation between religious and intention for voting is not significant with $\mathrm{P}$ value more than 0.05 . Results shows that that social media significant level is (Beta $=0.435)$ and ethnicity significant level is $($ Beta $=0.321)$. 


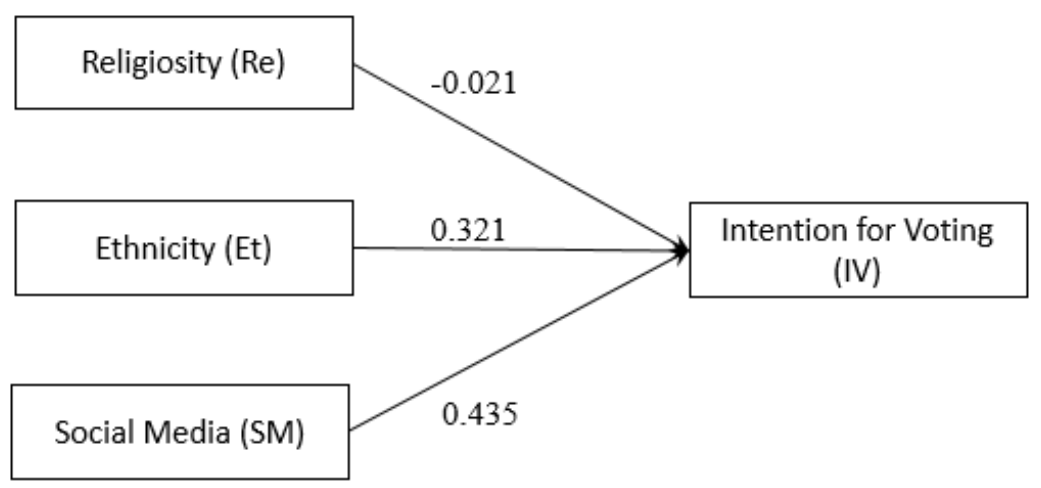

Fig. 2 Path Coefficient values

Table 6 Path Coefficient values

\begin{tabular}{lcccc}
\hline & $\begin{array}{l}\text { Path Coefficient } \\
(\text { Beta) }\end{array}$ & Standard Deviation & T Statistics & P Value \\
\hline $\mathrm{Et} \rightarrow \mathrm{IV}$ & 0.321 & 0.118 & 7.909 & 0.000 \\
\hline $\mathrm{Re} \rightarrow \mathrm{IV}$ & -0.021 & 0.139 & 0.254 & 0.799 \\
\hline $\mathrm{SM} \rightarrow \mathrm{IV}$ & 0.435 & 0.112 & 11.453 & 0.000 \\
\hline
\end{tabular}

\section{Discussion}

Three relations were tested in this study. The first hypothesis to assess the positive significant relation between ethnicity and intention for voting is accepted. The second hypothesis to assess the positive significant relation between religiosity and intention for voting is rejected. The third hypothesis to assess the positive significant relation between social media and intention for voting is accepted. The best predictor of intention for voting is social media with estimation level of 0.435 and the second predictor is ethnicity with estimation level of 0.321 .

Ethnicity have an impact while religiosity have no impact which confirms the separation between the two characteristics in forming the groups belonging in societies. The rejected relation of religiosity in Pakistan could be cite to ethnicity power; the belonging of individuals to the social groups is based on ethnicity rather than religiosity. The power of social media affect on people perception is confirmed in this study and for sure are mapped with many prior studies which was discussed in the literature review. 


\section{Recommendations}

Results shows the importance of social media and ethnicity in political issues; therefore politician and politicians management must give more attention to plan for ethnic-oriented political campaign delivered over social media networks. Use of social media to influence people's behaviour should be kept under control and supervision of non-biased third-party regulatory bodies to ensure that the platforms are not being used to brainwash people to instigate rebellions. Campaign managers need to conduct continued examination and understanding of the needs that draw users to Facebook pages to be able to create content that drives certain users' participation toward specific measurable offline outcomes.

Pakistan is emerging economy and so, has many challenges in every segment which require prompt change process to adopt new products like kid sanitize or social change towards fertility or political adaptation for new candidate for progress. Only change is constant and social media could help in tilting cognitive approach toward various parameter. Social Media has become global phenomena for change with its interactive and instant communication platform. Further research could be taken forward on how Social Media could bring positive change in country without sacrificing local culture and tradition.

Results highlight on the importance of social media in voting involvement aspects, therefore further research is recommended to replicate the study in different environments. Moreover, extending the criterion to investigate actual voting participation is recommended.

\section{Conclusion}

This paper investigated the impact of ethnicity, religiosity, and social media on improving the intention for voting. Two antecedents, ethnicity and religiosity, are traditional and commonly used to represent the individual belonging to a certain group, but the third antecedent social media is representing the revolutionary use of social media in political issues.

First, the relation between ethnicity and intention for voting is accepted. The more belonging to ethnicity group the more intention for voting. The result is rational and could be referred to the subjective norm of the group peers on the individual values and intention.

Second, the relation between religiosity and intention for voting is rejected. The results shows no impact between the individual participation on religiosity activities and his intention for voting. This finding shows that individual thought is influenced by the ethnicity group rather than the religiosity group in Pakistani society. This result could be rational for societies like Pakistan where there is strong belongings to ethnicity group in a multi-ethnicity environment, but it could be different in other uniethnicity environments.

Third, the relation between social media and intention for voting is accepted. The more individual engagement in social media network such as Facebook the more intention for voting. The result assures that political domain is also impacted by the revolutionary social media sites as a technique for diffusing ideas and impacting others. 


\section{References}

Ahmed, S., \& Skoric, M. M. (2014). My name is Khan: The use of Twitter in the campaign for 2013 Pakistan General Election. In 2014 47th Hawaii International Conference on System Sciences (pp. 2242-2251). IEEE.

Ajzen, I., \& Fishbein, M. (1980). Understanding attitudes and predicting social behaviour.

Ajzen, I. (1985). From intentions to actions: A theory of planned behavior. In Action control (pp. 11-39). Springer.

Argue, A., Johnson, D. R., \& White, L. K. (1999). Age and religiosity: Evidence from a three-wave panel analysis. Journal for the Scientific Study of Religion, 423-435.

Awami Politics. (2015). Top 5 Religious Political Parties in Pakistan. Retrieved from http://www.awamipolitics.com/top-5-religious-political-parties-in-pakistan-21491.html

Ayanso, A., Cho, D. I., \& Lertwachara, K. (2014). Information and communications technology development and the digital divide: A global and regional assessment. Information Technology for Development, 20(1), 60-77.

Bandura, A. (1977). Self-efficacy: toward a unifying theory of behavioral change. Psychological Review, 84(2), 191.

Birkbak, A. (n.d.). Towards a sociology of mediated publics.

Bronfenbrenner, U. (1977). Toward an experimental ecology of human development. American Psychologist, 32(7), 513.

Chandra, K. (2012). Constructivist theories of ethnic politics. Oxford University Press.

Cialdini, R. B., Kallgren, C. A., \& Reno, R. R. (1991). A focus theory of normative conduct: A theoretical refinement and reevaluation of the role of norms in human behavior. Advances in Experimental Social Psychology, 24, 201-234.

Dalbey, J. (2013). Community-Based Chamber Ensembles: How to Build a Career that Infuses Performance with Public Service. Arizona State University.

Davis, R. (1999). The web of politics: The Internet's impact on the American political system. Oxford University Press.

Duriez, B., Fontaine, J. R. J., \& Hutsebaut, D. (2000). A further elaboration of the Post-Critical Belief scale: Evidence for the existence of four different approaches to religion in Flanders-Belgium. Psychologica Belgica, 40(3), 153-182.

Duriez, B., Luyten, P., Snauwaert, B., \& Hutsebaut, D. (2002). The importance of religiosity and values in predicting political attitudes: Evidence for the continuing importance of religiosity in Flanders (Belgium). Mental Health, Religion \& Culture, 5(0), 35-54. https://doi.org/10.1080/13674670110066831

Enli, G., Larsson, A., Kalsnes, B., Skogerbø, E., Moe, H., Bruns, A., \& Artieri, G. B. (2013). Social media and elections: The use of Twitter in the 2013 campaigns in Italy, Australia, Germany, and Norway. Selected Papers of Internet Research, 3. 
Esposito, C. C. (2012). Can Political Candidates Use Facebook To Influence Real World Outcomes?, (May), 67.

Faris, D. (2010). Revolutions without revolutionaries? Social media networks and regime response in Egypt. Publicly Accessible Penn Dissertations, 116.

Hair, J. F. (2015). Essentials of business research methods. ME Sharpe.

Haq, R. (2011). Haq's Musings. Retrieved from http://www.riazhaq.com/2011/11/pakistans-protestmusic-in-social-media.html

Harvard IOP. (2015). Race and Ethnicity Still Play a Role In Political Attitudes. Retrieved from http://iop.harvard.edu/race-and-ethnicity-still-play-role-political-attitudes

Holdcroft, B. (2006). What Is Religiosity?. Catholic Education: A Journal of Inquiry and Practice, 10(1), 89-103.

Horowitz, D. L. (1985). Ethnic groups in conflict. Univ of California Press.

Ikstens, J. (2015). Personality traits and political attitudes in ethnically divided society: evidence from Latvia, 1-17.

Ingersoll-Dayton, B., Krause, N., \& Morgan, D. (2002). Religious trajectories and transitions over the life course. The International Journal of Aging and Human Development, 55(1), 51-70.

Johnson, A. E. (2007). Application of the theory of planned behavior to understand voting behaviors of the young electorate. In annual meeting of the International Communication Association, San Francisco, CA.

Kemp, S., Kendal, J., Warren, A., Wright, L., Canning, J., Grace, M., \& Saunders, C. (2015). Global Consensus Is a Dream, but Twitter Is Real: Simulating a Sustainable Development Goals Summit Through Interdisciplinary Classroom Politics and Negotiation by Social Media. In Integrative Approaches to Sustainable Development at University Level (pp. 551-566). Springer.

Khan, Z. S., \& Shahid, Z. (2010). Use of Social Media for Political Participation the Pakistani Students' Perspective.

Khan Minhas, M. F., Abbasi, R. A., Aljohani, N. R., Albeshri, A. A., \& Mushtaq, M. (2015). INTWEEMS: a framework for incremental clustering of tweet streams. In Proceedings of the 17th International Conference on Information Integration and Web-based Applications \& Services (p. 87). ACM.

Lampa, S., Dahlö, M., Olason, P. I., Hagberg, J., \& Spjuth, O. (2013). Lessons learned from implementing a national infrastructure in Sweden for storage and analysis of next-generation sequencing data. GigaScience, 2(1), 9.

Liu, C. (2015). Worldwide Internet and Mobile Users. eMarketer, (August), 30.

Logan, J. R., Darrah, J., \& Oh, S. (2012). Context on Participation in American Electoral Politics, 90(3). https://doi.org/10.1093/sf/sor024.The

Maloney, E. K., Lapinski, M. K., \& Neuberger, L. (2013). Predicting land use voting behavior: Expanding our understanding of the influence of attitudes and social norms. Journal of Applied Social Psychology, 43(12), 2377-2390. 
Margolis, M. (2014). Rethinking the Relationship between Religion and Politics: A Test of the Life Cycle Theory. Retrieved from http://www.michelemargolis.com/uploads/2/0/2/0/20207607/life_cycle_theory. pdf

Masood, E. (2013). Pakistan must seize the chance to revive its science. Nature, 500(7460), 7.

Miller, N. E., \& Dollard, J. (1941). Social learning and imitation.

Patel, K. (2015). Politics And Media Social Media In The Indian Context:-New Flavor Of The Season. Global Journal of Multidisciplinary Studies, 4(6).

Phinney, J., \& Ong, A. (2006). Testing competing models of the structure of ethnic identity with the Multigroup Ethnic Identity Measure. Unpublished Manuscript.

Schwartz, S. H., \& Huismans, S. (1995). Value priorities and religiosity in four western religions. Social Psychology Quterly, 88-107.

Shehzad, A. (2011). The Issue of Ethnicity in Pakistan: Historical Background. Pakistan Vision, 12(2), 124.

Singh, K., Leong, S. M., Tan, C. T., \& Wong, K. C. (1995). A theory of reasoned action perspective of voting behavior: Model and empirical test. Psychology \& Marketing, 12(1), 37-51.

Van Gyes, G., \& De Witte, H. (1999). Conservatism and values: A confrontation of Middendorp with Schwartz and Triandis.

Varshney, A. (2003). Ethnic conflict and civic life: Hindus and Muslims in India. Yale University Press.

Wang, A. T., Sandhu, N. P., Wittich, C. M., Mandrekar, J. N., \& Beckman, T. J. (2012). Using social media to improve continuing medical education: a survey of course participants. In Mayo Clinic Proceedings (Vol. 87, pp. 1162-1170). Elsevier.

Wang, A. T., Sandhu, N. P., Wittich, C. M., Mandrekar, J. N., \& Beckman, T. J. (2012). Using social media to improve continuing medical education: a survey of course participants. In Mayo Clinic Proceedings (Vol. 87, pp. 1162-1170). Elsevier.

Wilson, J., \& Sherkat, D. E. (1994). Returning to the Fold. Journal for the Scientific Study of Religion, $148-161$.

Worthington Jr, E. L., Wade, N. G., Hight, T. L., Ripley, J. S., McCullough, M. E., Berry, J. W., ... O'Connor, L. (2003). The Religious Commitment Inventory--10: Development, refinement, and validation of a brief scale for research and counseling. Journal of Counseling Psychology, 50(1), 84.

Xenos, M., Vromen, A., \& Loader, B. D. (2014). The great equalizer? Patterns of social media use and youth political engagement in three advanced democracies. Information, Communication \& Society, $17(2), 151-167$.

Yusuf, H. (2015). New Media in Naya Pakistan: Technologies of Transformation or Control? Pakistan's Enduring Challenges, 156. 


\section{Copyrights}

Copyright for this article is retained by the author(s), with first publication rights granted to the journal.

This is an open-access article distributed under the terms and conditions of the Creative Commons Attribution license (http://creativecommons.org/licenses/by/4.0/). 